\title{
ОРГАНІЗАЦІЯ ТА ВДОСКОНАЛЕННЯ САМОСТІЙНОЇ ДОСЛІДНИЦЬКОЇ ДІЯЛЬНОСТІ СТУДЕНТІВ ЧОРТКІВСЬКОГО МЕДИЧНОГО КОЛЕДЖУ
}

\author{
А. Б. Валинюк, С. О. Коноваленко \\ Чортківський державний медичний коледж \\ двнЗ «Тернопільський державний медичний університет \\ імені І. Я. Горбачевського МОЗ Украӥни»
}

У статті проаналізовано теоретико-методологічні засади організації самостійноїдослідницькоїдіяльності та розроблено підходи до спрямування самостійної роботи студентів медичного коледжу на розвиток знань, вмінь та якостей, що будуть необхідними для вирішення навчальних завдань.

\section{ORGANIZATION AND IMPROVEMENT OF STUDENTS’ INDEPENDENT EXPLORATORY ACTIVITY IN CHORTKIV MEDICAL COLLEGE}

\author{
A. B. Valynuk, S. O. Konovalenko \\ Chortkiv State Medical College \\ I. Horbachevsky Ternopil State Medical University
}

\begin{abstract}
The article analyzes theoretical and methodological principles of students' independent exploratory activity in medical college and develops approaches to directing independent work on the development of knowledge, skills and qualities that will be needed to solve educational problems.
\end{abstract}

Вступ. У системі медичної освіти України останнім часом значно збільшується частка та важливість самостійної роботи студентів. Система вищої освіти зосереджується не лише на набутті студентами визначеної освітньо-кваліфікаційною характеристикою певної сукупності знань, професійних умінь та навичок, розвитку творчого мислення, але й на оволодінні ними методикою самостійного пошуку й аналізу інформації, які $\epsilon$ необхідними для безперервного вдосконалення під час навчання та в професійній діяльності. Педагогічна практика свідчить, що основу кваліфікаційного рівня майбутнього фахівця визначає набутий ним особисто досвід вирішення практичних завдань. Незалежність мислення, мотивація до здобуття нових знань та опанування методами наукового пізнання формується в процесі самостійної дослідницької діяльності.

Основна частина. Самостійна робота $\epsilon$ необхідною не лише для оволодіння необхідними знаннями, але й для формування навичок самостійної роботи в навчальній, науково-дослідницькій та професійній діяльності, що дозволяє у майбутньому самостійно вирішувати поставлені завдання, знаходити ефективні шляхи вирішення нестандартних ситуацій, брати на

(C) А. Б. Валинюк, С. О. Коноваленко, 2017 себе відповідальність за них. Самостійна діяльність сприяє розвитку таких вольових та особистісних якостей, як наполегливість, зосередженість, організованість та ініціативність тощо.

Вагому роль самостійної роботи в навчальному процесі підкреслено в класичній педагогічній літературі, а також у працях зарубіжних і вітчизняних науковців, здобутки яких стали теоретико-методологічною основою даного дослідження. Віддаючи належне внеску попередників відзначимо, що ними закладено фундамент для розробки педагогічних методик організації самостійної роботи в процесі здобуття професійної освіти за різними галузями знань $[2,7]$. Саме практична потреба в адаптації кращого досвіду організації самостійної роботи до навчального процесу студентів медичного коледжу визначає актуальність даного дослідження.

Метою роботи $\epsilon$ аналіз теоретико-методологічних засад організації самостійної дослідницької діяльності та розробка підходів до спрямування самостійної роботи студентів II курсу медичного коледжу на розвиток знань, вмінь та якостей, що будуть необхідними для вирішення навчальних завдань в подальшому. Враховуючи те, що тема організації самостійної роботи 
студентів (СРС) у вищій професійній освіті $\epsilon$ досить добре розвинутою, у баченні цього поняття відсутня єдність думок, про що свідчать результати аналізу науково-методичної літератури. Зокрема, термін «самостійна робота» тлумачиться, як: а) самостійний пошук необхідної інформації, здобуття знань, їх використання для вирішення навчальних, наукових та професійних завдань; б) діяльність, яка складається з багатьох елементів: творчого сприйняття й осмислення навчального матеріалу під час лекцій, підготовки до занять, іспитів, заліків та опрацювання медичної документації, підготовки санбюлетенів при проходженні виробничої та переддипломної практики; в) різноманітні види індивідуальної, групової пізнавальної діяльності студентів на заняттях або в позааудиторний час без прямого керівництва, але під контролем викладача [1, 4]. Організація СРС у вищих навчальних закладах розглядається як система педагогічних заходів, що спрямовані на: а) розвиток таких особистісних рис, як ініціативність та самостійність; б) вироблення умінь і навичок ефективного пошуку та опрацювання потрібної для виконання навчальних (професійних) завдань інформації $[2,8]$. Окремі дослідники вбачають у самостійній роботі систему організації педагогічних умов, з виконанням яких забезпечується керованість тієї навчально-пізнавальної діяльності студентів, яка відбувається без безпосередньої участі викладача $[3,11]$. Вдосконалення та організація самостійної роботи студентів як складової навчального процесу, спрямованого на контрольований розвиток ними своїх знань, вмінь та навичок, здійснюється з урахуванням певних дидактичних принципів, на сутності яких позначається специфіка галузевого напрямку педагогічної діяльності.

Умови організації СРС характеризують потенціал студентів, зокрема, їх особисту вмотивованість до навчання та саморозвитку. Мотивація виконує три регулювальні функції відносно навчальної діяльності: спонукальну, змістотворчу, організаційну. Описана мотиваційна структура формує основу для пізнавальної активності суб'єкта навчального процесу, тому її розвиток має бути метою та сутністю освітнього процесу, особливо, на II курсах, коли в свідомості студента формується образ його професійної та суспільної самоідентифікації.

Відзначимо, що якість мотиваційної структури у студентів може відрізнятися. Наприклад, в однієї частини вона має генезисний характер та виявляється в стійкому прагненні до здобуття нових знань, а в іншої частини студентів розвиток цих якостей варто стимулювати через таку організацію навчального процесу, коли самостійна робота стає його основною ланкою. Отже, головна мета самостійної роботи та зусиль викладачів на II курсі коледжу має полягати у формуванні мотивації до пізнавально-навчальної діяльності. В цілому, головне завдання кожного педагога та освітнього процесу полягає в тому, щоб навчити студента самостійно використовувати свій інтелектуальний, психологічний, творчий і мотиваційний ресурс, а не звинувачувати його в незнанні фактичного матеріалу. Необхідно допомогти студенту перейти від «формального» мотиву (наприклад, вивчити матеріал, щоб не отримати незадовільну оцінку) до цілком усвідомленої самостійної пізнавальної діяльності (наприклад, студент ставить за мету вдосконалення професійно значущих знань і вмінь для того, щоб забезпечити собі переваги під час вступу до вищого навчального закладу III-IV рівнів акредитації чи під час первинного працевлаштування тощо) $[9,10]$.

У навчальному процесі вибір оптимальних форм і видів СРС значно впливає на ефективність співпраці викладача та студента. На нашу думку, з огляду на місце та час проведення занять, характеру керівного впливу з боку викладача, а також методів контролю результативності, на II курсі медичного коледжу варто використовувати такі форми та види СРС:

- систематичне читання і конспектування літератури;

- написання рефератів, доповідей, підготовка мініпроектів;

- аналіз наукової публікації з наперед визначеної викладачем теми;

- самостійне опрацювання даних, отриманих під час спостережень, обговорення їх у групах;

- проведення санітарно-просвітньої роботи;

- виконання студентом завдань навчального і творчого характеру.

Отже, результативність СРС визначається наявністю активних методів ії контролю як на проміжному, так і на підсумковому рівнях. Контроль повинен мати систематичний характер насамперед для того, щоб виявити недоліки в освітньому процесі та створити механізм їх усунення, забезпечити зворотний зв'язок для корегування навчання $[5,6]$.

Використовують різноманітні форми контролю вони можуть бути усними або письмовими, індивідуальними або в групі, вибірковими або суцільними. Поряд із традиційними формами, контроль самостійної роботи може бути заснований на рейтинговій 
системі, яка передбачає регулярне відстеження якості оволодіння знаннями та вміннями, виконання планового обсягу самостійної роботи $[1,9]$. Враховуючи вищенаведене нами розроблено рекомендації стосов- но урізноманітнення змісту СРС під час проведення практичних занять з основ сестринської справи для студентів II курсу медичного коледжу за спеціальністю «Сестринська справа» (табл.).

\section{Таблиця. Рекомендації щодо удосконалення самостійної роботи з практичних занять з основ сестринської справи}

\begin{tabular}{|c|c|c|c|}
\hline $\begin{array}{c}\text { № } \\
\text { заняття }\end{array}$ & Тема заняття & Самостійна робота & Контроль \\
\hline 1 & $\begin{array}{l}\text { Система охорони } \\
\text { здоров'я в Україні. } \\
\text { Історія медсестринської } \\
\text { справи. Охорона праці } \\
\text { в галузі }\end{array}$ & $\begin{array}{l}\text { Ознайомитися з інструкцією з охорони праці для медич- } \\
\text { ної сестри, яка працює у медичній галузі. Ознайомитися з } \\
\text { основними шкідливими виробничими факторами умов } \\
\text { праці. Самостійно підготувати рекомендації щодо створен- } \\
\text { ня безпечного лікарняного середовища }\end{array}$ & $\begin{array}{l}\text { Тестовий } \\
\text { контроль, } \\
\text { вирішування } \\
\text { ситуаційних задач }\end{array}$ \\
\hline 2 & $\begin{array}{l}\text { Медсестринський про- } \\
\text { цес. Етапи медсестрин- } \\
\text { ського процесу }\end{array}$ & $\begin{array}{l}\text { Вивчити значення сестринського обстеження для вияв- } \\
\text { лення проблем пацієнта. Студент повинен ознайомитися з } \\
\text { методикою проведення суб'єктивного і об'єктивного мето- } \\
\text { дів обстеження пацієнта. Виявляти фактори, що сприяють } \\
\text { і заважають спілкуванню. Студент повинен знати різницю } \\
\text { між проблемою пацієнта і медичним (лікарським) діагно- } \\
\text { зом. Навчитися заповнювати план сестринського догляду }\end{array}$ & Практичне \\
\hline 3 & $\begin{array}{l}\text { Формування здорового } \\
\text { способу життя, профі- } \\
\text { лактика захворювань }\end{array}$ & $\begin{array}{l}\text { Підготувати матеріал про захворювання, що виникають } \\
\text { при недостатній фізичній активності. } \\
\text { Підготувати проектні роботи про значення руху для } \\
\text { здоров'я людини: } \\
\text { - вплив фізкультури на серцево-судинну систему; } \\
\text { - вплив фізкультури на органи дихання; } \\
\text { - вплив фізичних вправ на опорно-руховий апарат; } \\
\text { - вплив фізичних вправ на ендокринну та інші системи } \\
\text { організму; } \\
\text { - фізичні вправи запобігають ожирінню }\end{array}$ & $\begin{array}{l}\text { Розв'язування } \\
\text { ситуаційних задач. } \\
\text { Письмово } \\
\text { (проектні роботи) }\end{array}$ \\
\hline 4 & Рух і здоров'я & $\begin{array}{l}\text { Ознайомитися з проведенням ортостатичної проби, проби } \\
\text { на присідання, на затримку дихання, вимірювання сили } \\
\text { м'язів за допомогою динамометра }\end{array}$ & Практичне \\
\hline 5 & $\begin{array}{l}\text { Раціональне } \\
\text { харчування }\end{array}$ & $\begin{array}{l}\text { Студент повинен навчитися визначати масу тіла, ви- } \\
\text { мірювати зріст. Підготувати матеріал про визначення } \\
\text { нормальної та ідеальної форми тіла (за формулами). } \\
\text { Навчитися складати меню для різних вікових груп залеж- } \\
\text { но від інтенсивності праці }\end{array}$ & $\begin{array}{l}\text { Тестовий } \\
\text { контроль }\end{array}$ \\
\hline 6 & $\begin{array}{l}\text { Загартовування орга- } \\
\text { нізму. Психічна само- } \\
\text { регуляція }\end{array}$ & $\begin{array}{l}\text { Ознайомитися з методикою проведення самоаналізу } \\
\text { пам'яті та проведення самоаналізу концентрації уваги. } \\
\text { Підготувати самостійно міні-проекти на тему «яке має для } \\
\text { здоров'я людини значення загартовування.» }\end{array}$ & $\begin{array}{l}\text { Розбір } \\
\text { ситуаційних } \\
\text { задач. Письмово } \\
\text { (проектні роботи) }\end{array}$ \\
\hline 7 & $\begin{array}{l}\text { Типи ЛПЗ. Інфекційна } \\
\text { безпека. Інфекційний } \\
\text { контроль }\end{array}$ & $\begin{array}{l}\text { Підготувати матеріал структури поліклініки, її функції, } \\
\text { медсестринського персоналу, види медичної документа- } \\
\text { ції. Типи лікарень, їх функції. Ознайомитися з посадовими } \\
\text { обов'язками медсестринського персоналу лікарні. Опрацю- } \\
\text { вати матеріал роботи терапевтичного відділення лікарні }\end{array}$ & $\begin{array}{l}\text { Тестовий } \\
\text { контроль }\end{array}$ \\
\hline 8 & Прийом пацієнтів & $\begin{array}{l}\text { Ознайомитися з діяльністю сестринського персоналу в } \\
\text { приймальному відділенні. Вміти переконувати пацієнта } \\
\text { в потребі дотримуватися призначеного режиму фізичної } \\
\text { активності, здійснювати повну або часткову санітарну } \\
\text { обробку пацієнта }\end{array}$ & Практичне \\
\hline 9 & $\begin{array}{l}\text { Особиста гігієна } \\
\text { пацієнта }\end{array}$ & $\begin{array}{l}\text { Підготувати санітарно-просвітню роботу: «Роль медичної } \\
\text { сестри в підтриманні особистої гігієни пацієнта» }\end{array}$ & Проектні роботи \\
\hline 10 & $\begin{array}{l}\text { Застосування лікар- } \\
\text { ських засобів }\end{array}$ & $\begin{array}{l}\text { Ознайомитися з чинними наказами МОЗ України про облік } \\
\text { та видачу наркотичних, сильнодіючих, гостродефіцитних } \\
\text { лікарських засобів. Особливостями виписування та } \\
\text { отримання лікарських засобів з аптеки. Самостійно } \\
\text { опрацювати техніку зовнішнього застосування лікарських } \\
\text { засобів, ентерального введення лікарських засобів }\end{array}$ & Практичне \\
\hline
\end{tabular}


Впровадження запропонованих заходів у самостійну роботу студентів має на меті такі цілі:

- розвиток інтелектуальних, дослідницьких та особистісних якостей студентів шляхом урізноманітнення форм самостійної позааудиторної роботи в межах практикуму з курсу «Основ сестринської справи», які обмежувалися підготовкою питань для письмового контролю знань (самостійні роботи), підготовкою альбомів, рефератів, проектних робіт;

- спонукання індивідуальної пізнавальної активності через усвідомлення студентами закономірностей перебігу досліджуваних явищ;

- розвиток навичок роботи з друкованими та цифровими джерелами інформації, опрацювання графічних та текстових блоків даних;

\section{СПИСОК ЛІТЕРАТУРИ}

1. Буряк В. Самостійна робота як системоутворюючий елемент навчальної діяльності студентів / В. Буряк // Вища школа. - 2008. - № 5. - С. 10-24.

2. Дзюба І. О. Організація самостійної роботи студентів вищих навчальних закладів в умовах особистісно-орієнтованого навчання [Електронний ресурс] / І. О. Дзюба. Харків, 2008. - Режим доступу : http://www. bestreferat. ru/referat-136461. html

3. Журавель В. Самостійна робота як складова професійної підготовки студента коледжу: теоретичний аспект / В. Журавель // Вісник інституту розвитку дитини. - 2013. № 29. - С. 51-55.

4. Кечик О. О. Форми та методи самостійної роботи студентів педагогічного коледжу / О. О. Кечик // Науковий вісник Донбасу. - 2011. - № 1. - С. 42-45.

5. Кудрявцева Т. О. Позааудиторна самостійна робота студентів як складова підготовки майбутніх медичних сестер до розв'язання проблемних ситуацій в професійній діяльності / Т. О. Кудрявцева // Збірник наукових праць Харківського університету Повітряних Сил. - 2011. № 2. - С. 192-194.

6. Методичні рекомендації для практичних занять з біології для студентів I курсу медичного коледжу за
- розвиток навичок презентації науково-дослідницької інформації під час проведення семінарів, зачитування доповідей;

- заохочення самостійної роботи студентів шляхом врахування ії результативності в підсумковому оцінюванні.

Висновки. Самостійна дослідницька діяльність студентів потребує ґрунтовної переоцінки засад організації навчального процесу, який повинен будуватися так, щоб посилювати бажання здобувати нові знання, формувати орієнтованість до саморозвитку та вміння творчо застосовувати отримані знання в процесі вирішення навчальних завдань, та, врешті-решт, сприяти підвищенню конкурентоспроможності випускників медичного коледжу на ринку праці та освітніх послуг.

спеціальністю «Сестринська справа та лікувальна справа». - Івано-Франківськ : Івано-Франківський базовий медичний коледж, 2012. - 15 с.

7. Организация самостоятельной работы студентов в педагогическом вузе / В. С. Елагина, Е. Ю. Немудрая, Л. М. Конев, О. Р. Михайлова // Современные наукоемкие технологии. - 2010. - № 10. - С. 116-118.

8. Петунин О. В. Система активизации познавательной самостоятельности учащихся / О. В. Петунин // Вестник Московского университета. - 2010. - № 4. - С. 63-70.

9. Пичкова Л. С. Организация самостоятельной работы студентов как фактор формирования профессионально значимых компетенций / Л. С. Пичкова // Пути повышения конкурентоспособности экономики России в условиях глобализации : материалы конференции. М. : МГИМО-Университет, 2008. - 121 с.

10. Томашевская О. Б. Сущность и содержание самостоятельной работы студентов в условиях вуза / О. Б. Томашевская, Н. А. Малиновская // Вестник Балтийского федерального университета им. И. Канта. - 2011. № 11. - С. 112-117.

11. Туркот Т. І. Педагогіка вищої школи : навч. посіб. / Т. І. Туркот. - К. : Кондор, 2011. - 628 с. 